\title{
Molecular Phylogeny of four bivalve species collected from Egyptian Mediterranean and Red Sea based on mitochondrial $C O 1$ gene sequences
}

\section{Nancy A. Radwan ${ }^{1}$, Mohammed I. Ahmed ${ }^{2}$, Nesreen K. Ibrahim ${ }^{2}$, Saad Z. Mohammed ${ }^{2}$ and Zakaria S. Morsy ${ }^{1}$.}

1- Department of Zoology, Faculty of Science, El Arish, Suez Canal University, Egypt.

2- Department of Marine Science, Faculty of Science, Ismailia, Suez Canal University, Egypt

\section{ABSTRACT}

The marine bivalve (family Veneridae and Mytilidae) are dominant groups in terms of species numbers, diversity of habitat and economical importance. The aim of the current study is to gain new insights onto the phylogeny of four different species of bivalvein Egypt. Partial sequence of the mitochondrialcytochrome oxidase subunit 1 (CO1) is sequenced to assess whether different species of bivalve could be distinguished by DNA barcoding technique. The obtained molecular results revealed the efficacy of DNA barcoding in species identification and differentiation between the different species.

Keywords: Phylogeny, DNA barcoding, mitochondrial cytochrome oxidase subunit 1 (CO1).

\section{INTRODUCTION}

The phylogeny of Mollusca is a controversial subject; in fact some of the traditionally classified molluscs may be redefined as distinct but related (Goloboff et al., 2009). More than $99 \%$ of living molluscan species belong to two classes (Gastropoda and Bivalvia).

Bivalves are species that probably need common tools and methods in order to have a clear picture about their relationships where different approaches are using genetic markers to understand phylogenetic, population structure, taxonomy, ecology.....etc (David and Savini, 2011).

Many marine taxa represent an ideal target for DNA barcoding due to a lack of reliable morphological characters for easy diagnosis. One of the most frequently used regions of the mitochondrial (mt) DNA is cytochrome c oxidase subunit 1 (COl) (Feral, 2002). It is the most used marker in molecular studies and barcoding (Hebert et al., 2003). This marker is a phylogenetical signal stronger than any other mitochondrial markers, where it can discriminate not only among strongly related species but also among phylogroups belonging to the same species (Hebert et al., 2003a). Also, COl shows distinct divergence and provides valuable information in species identification to complete taxonomic data and validation of systemic position and phylogeny (Machordom et al., 2003; Smith et al., 2004; Donald et al., 2005).

Despite the importance of bivalve in marine biota, their deeply phylogenetic relationships were scarcely investigated from a molecular perspective, whereas much valuable work has been done on taxonomy, as well as physiology, of the lower taxa (Plazzi et al., 2011).

Due to the limitation of the information about the molecular studies on species of family veneridae and mytilidae in Egypt, the present study focused onidentification the species of family veneridae (Paphia sp. and Polititapes sp.) and family mytilidae (Modiolus sp. and Brachidontes sp.) in Egypt based on DNA barcoding. The General 
aim is to develop a fast and easy method for identification by using the molecular examination of nucleotide sequence for $\mathrm{CO} 1$ gene.

\section{MATERIALS AND METHODS}

\section{Study areaand Sample collection}

Fifteen individual of bivalve samples were collected for molecular examination during the summer 2012-2013. They were Paphia sp. and Polititapes sp. from Lake Timsah; Modiolus sp. from Marsa Alam and Brachidontes sp. from Lake Bardawil (Fig.1).

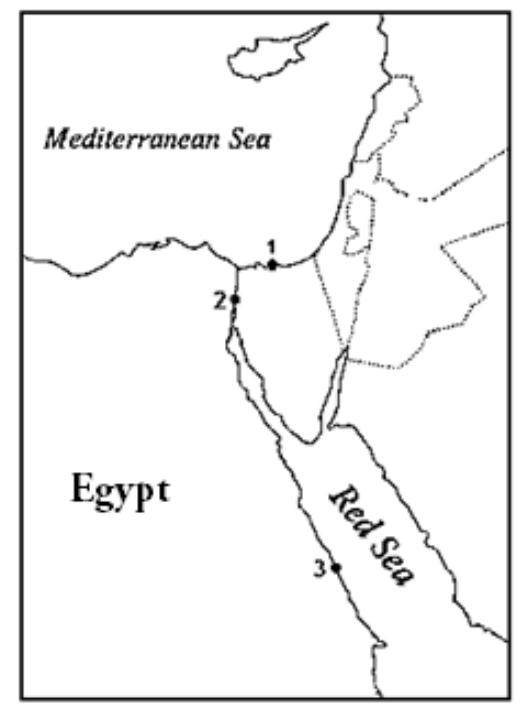

Fig. 1: Map showing the sites of collection of different bivalve species1: Lake Bardawil; 2: Lake Timsah; 3: MarsaAlam.

\section{gDNA Extraction, PCR amplification and sequencing}

The samples were frozen at $-70^{\circ} \mathrm{c}$ and the gDNA was extracted froma very small piece of foot using the phenol-chloroform (CTAB) procedure as described by Coffroth et al. (1992), and then the DNA was stored at $-20{ }^{\circ} \mathrm{c}$. A small region $(\sim 600-$ 700 bps) of the mitochondrial CO1 gene was amplified in the thermocycler (Major Science Thermocycler) using the universal primers described by Folmer et al. (1994):

LCO1490 (F): 5'-GGTCAACAAATCATAAAGATATTGG-3'.

HCO2198 (R): 5'-TAAACTTCAGGGTGACCAAAAAATCA-3'.

PCR reaction was performed in $25 \mu \mathrm{l}$ volume containing $12.5 \mu \mathrm{l}$ Master Mix, $0.5 \mu 1$ of each primer (10 pmol), $6 \mu 1$ of template DNA (about 100 ngtemplate DNA) and sterile distilled water to final volume of $25 \mu \mathrm{l}$. To optimize PCR products, annealing temperature and times were varied. PCR conditions were as follows: an initial denaturation for $3 \mathrm{~min}$ at $94{ }^{\circ} \mathrm{C}$, followed by $45 \mathrm{sec}$ at $94{ }^{\circ} \mathrm{C}, 1 \mathrm{~min}$ at annealing temperature $52^{\circ} \mathrm{C}$ and $2 \mathrm{~min}$ at $72^{\circ} \mathrm{C}$ for 35 cycles, and a final extension of $5 \mathrm{~min}$ at $72 \circ \mathrm{C}$.

The PCR products were run on a $1.5 \%$ horizontal agarose gel stained with ethidium bromide. The bands were visualized and photographed in UV photodocumentation unit. Purification was carried out by using QIAquick PCR Purification Kit (QIAGEN). The purified PCR product was sequenced in Macrogen Ltd (Korea) and Biotechnology Research Center (Suez Canal University, Egypt) by (3500 Genetic Analyzer, Applied Biosystems). 


\section{Phylogenetic analysis}

Sequence chromatograms of COI sequences were edited for all taxa using MEGA V6.06 software and aligned using the Clustal W program then adjusted manually. The dataset for 27 specimens of speciesused in the present study with their accession number on GenBank are described in Table (1).

Table 1: Species included in analysis, with their collection localities and GenBank accession number.

\begin{tabular}{|c|c|c|c|}
\hline Species & Family & Locality & Accession number \\
\hline Modiolus sp. & Mytilidae & $\begin{array}{c}\text { Red Sea } \\
\text { MarsaAlam }\end{array}$ & KP164534 \\
\hline \multirow[t]{5}{*}{ Brachidontespharaonis } & \multirow[t]{5}{*}{ Mytilidae } & $\begin{array}{c}\text { Mediterranean Sea } \\
\text { Lake Bardawil }\end{array}$ & $\begin{array}{l}\text { KP164519 } \\
\text { KP164520 } \\
\text { KP164521 }\end{array}$ \\
\hline & & $\begin{array}{c}\text { Mediterranean Sea } \\
\text { Port Said }\end{array}$ & $\begin{array}{l}\text { KP164522 } \\
\text { KP164523 } \\
\text { KP164524 }\end{array}$ \\
\hline & & $\begin{array}{l}\text { Suez Canal } \\
\text { Lake Timsah }\end{array}$ & $\begin{array}{l}\text { KP164525 } \\
\text { KP164526 } \\
\text { KP164527 }\end{array}$ \\
\hline & & $\begin{array}{c}\text { Suez } \\
\text { Gulf of Suez }\end{array}$ & $\begin{array}{l}\text { KP164528 } \\
\text { KP164529 } \\
\text { KP164530 }\end{array}$ \\
\hline & & $\begin{array}{c}\text { Red Sea } \\
\text { MarsaAlam }\end{array}$ & $\begin{array}{l}\text { KP164531 } \\
\text { KP164532 } \\
\text { KP164533 }\end{array}$ \\
\hline Polititapesaureus & Veneridae & $\begin{array}{l}\text { Suez Canal } \\
\text { Lake Timsah }\end{array}$ & $\begin{array}{l}\text { KP164535 } \\
\text { KP164536 } \\
\text { KP164537 } \\
\text { KP164538 } \\
\text { KP164539 } \\
\text { KP164540 } \\
\text { KP164541 } \\
\text { KP164542 } \\
\text { KP164543 } \\
\text { KP164544 }\end{array}$ \\
\hline Paphia textile & Veneridae & $\begin{array}{l}\text { Suez Canal } \\
\text { Lake Timsah }\end{array}$ & KP164545 \\
\hline
\end{tabular}

Using Blast, $\mathrm{CO} 1$ sequences of the most related species of bivalves were screened on the NCBI GenBank data base. They were added to the present analysis to construct phylogenetic tree using MEGA 6 (Tamura et al., 2013).To generate the phylogenetic relationship between $\mathrm{CO}$ sequences for all bivalves in the current study and sequences from GenBank, Maximum likelihood tree was constructed with the Hasegawa-Kishino-Yano substitution model (Hasegawa et al., 1985) and Gamma distributed among sites $(\mathrm{HKY}+\mathrm{G})$ according to the lowest Bayesian Information Criterion (BIC) with bootstrap value $100 \%$,the tree was rooted by Laternula sp. (GU227114). Also, Neighbor-Joining tree based on p-distance (Saitou and Nei, 1987) was constructed for the phylogenetic relationship between all bivalve species collected from Egypt, the tree was rooted by Mactra veneriformis (JN674624). Each species of bivalve was represented by one individual in the phylogenetic tree.

\section{RESULTS}

The Maximum likelihood tree between $\mathrm{CO1}$ sequence for all bivalves in the current study and other bivalves collected from GenBank (Fig. 2) shows two major 
clads. The first comprises all species of family veneridae and the second clade includes the different species of family mytilidae.

Within each clade, the species from each subfamily were clustered together with their resemble species from GenBank with high bootstrap at each node. In the clade of family veneridae, $P$. aureus from Egypt and $P$. aureus (JX051549) were robustly grouped together; also $P$. textile was grouped with $P$. textile (JF969277). In clade of family mytilidae, Modiolus sp. from Egypt was closely related to Modiolus $s p$. (AB972412); and B. pharaonis was clustered with B. pharaonis (DQ836013). Also, the phylogenetic relationship between the four different species of bivalve in Egypt was confirmed by the Neighbor joining tree as shown in Fig. 3.

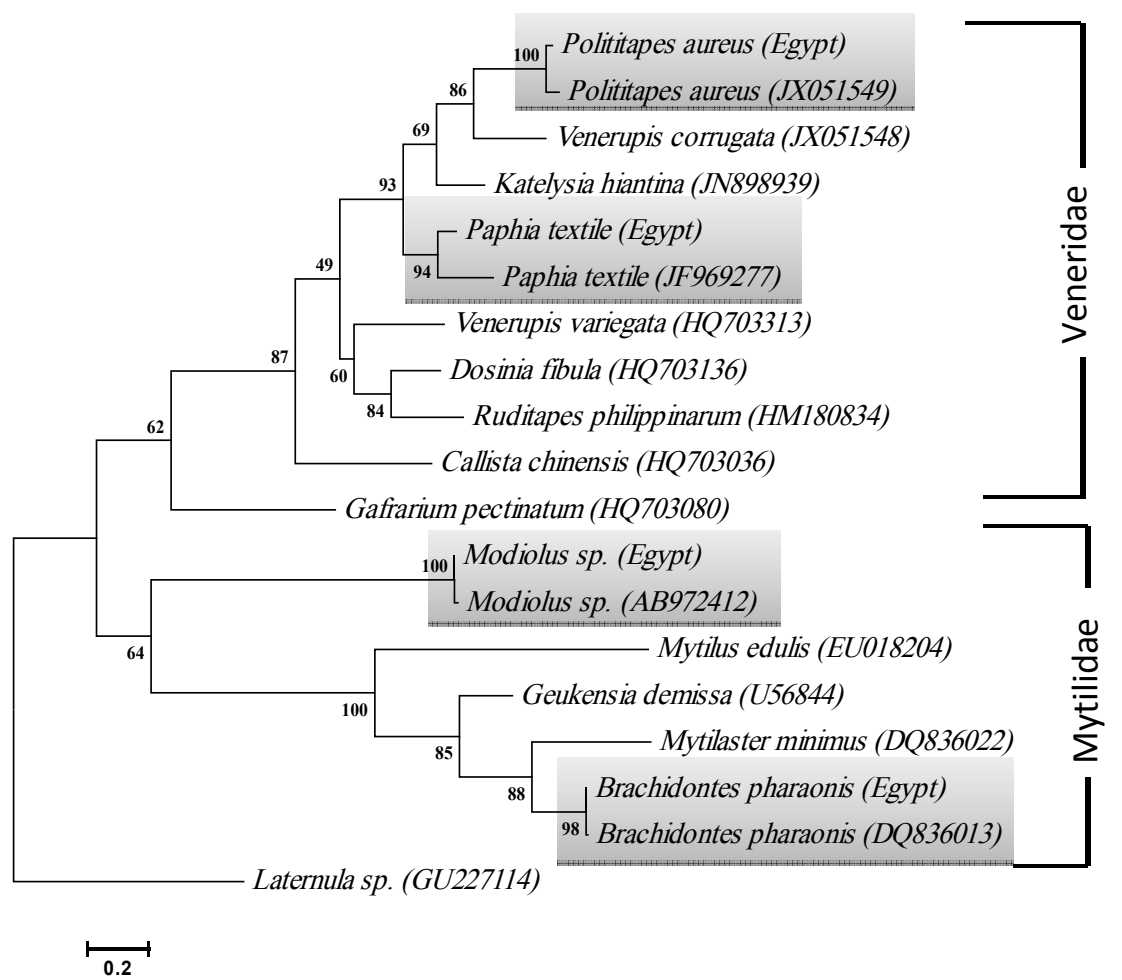

Fig. 2: Maximum likelihood tree for $\mathrm{COI}$ sequences of different species of bivalves collected from Egypt. Laternula $s p$. was used as outgroup.

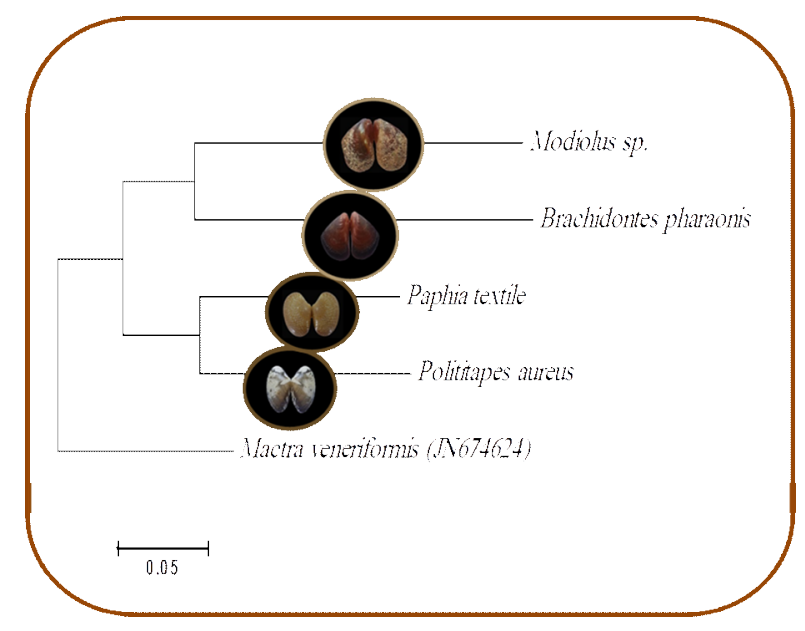

Fig. 3: Neighbor-Joining tree for $\mathrm{CO} 1$ sequences of different species of bivalves collected from Egypt. Mactra veneriformis was used as outgroup. 


\section{DISCUSSION}

In this study, PCR technique and direct sequencing of $\mathrm{COl}$ gene were selected to elucidate taxonomy of different bivalves and to understand their phylogenetic relationships with other bivalve species in the world that collected from GenBank.

Many authors used molecular method in many purposes like providing information on relationship between species (Huff et al., 2004; Mahidol et al., 2007; Espineira et al., 2009; Vierna et al., 2010), on their evolutionary history (Ahmed, 2010; Cunha et al., 2011; Etter et al., 2011); on genetic variation within species populations (Luttikhuizen et al., 2003; Zardus et al., 2006); on population size, migratory events, and biodiversity conservation issues such as hybridization events (Westfall and Gardner, 2010).

The present phylogenetic analysis revealed that using of DNA barcoding was successful and proved to be a good technique. The results were clear enough to identify and taxonomy the different bivalve species collected from Egypt (Polititapes aureus, Paphia textile, Brachidonte spharaonis, Modiolus sp.). Hebert et al. (2003) stated that DNA barcoding is proposed to be a new tool to achieve accurate, rapid and automatable species identification without morphological knowledge.

Moreover, using of $\mathrm{CO}$ sequence has demonstrated its ability to distinguish between the different families of bivalve (Veneridae and Mytilidae) in the current study and other bivalves collected from GenBank. Modiolus sp., Brachidonte spharaonis, Paphia textile, and Polititapes aureus from Egypt were unambiguously distinguishable from all other species and clustered only with their closely resemble sister species in GenBank with high bootstrap close to $100 \%$. The suitability of $\mathrm{CO}$ gene data in taxonomy has been shown in numerous other molecular analyses of bivalves (e.g. Park and Ó Foighil, 2000; Canapa et al., 2003; Cooley and Ó Foighil, 2000; Matsumoto, 2003; Roe et al., 2001).

\section{REFERENCES}

Ahmed, M.I. (2010). Morphological, Ecological and Molecular examination of the Seacucumber species along the Red Sea Coast of Egypt and Gulf of Aqaba, with the investigation of the possibility of using DNA barcoding technique as a standard method for Seacucumber ID. Ph.D. Thesis, Hull Univ.258pp.

Canapa, A.; Schiaparelli, S.; Marota, I. and Barucca, M. (2003). Molecular data from the 16S rRNA gene for the phylogeny of Veneridae (Mollusca: Bivalvia). Mar. Biol., 142 (6): 1125-1130.

Coffroth, M.A.; Lasker, H.R.; Diamond, M.E.; Bruenn, J.A. and Bermingham, E. (1992). DNA fingerprints of a gorgonian coral: a method for detecting clonal structure in a vegetative species. Mar. Biol., 114 (2): 317-325.

Cooley, L.R. and Ó Foighil, D. (2000). Phylogenetic analysis of the Sphaeriidae based on partial mitochondrial 16S rDNA sequences. Invert. Biol., 119: 299-308.

Cunha, R.L.; Blanc, F.; Bonhomme, F. and Arnaud-Haond, S. (2011). Evolutionary patterns in pearl oysters of the genus Pinctada (Bivalvia, Pteriidae). Mar.Biotechnol., 13: 181-192.

David, D.C. and Savini, D. (2011). Molecular approaches to bivalve population studies: a review.

Donald, K.M.; Kenned, Y.M. and Spencher, H.G. (2005). The phylogeny and taxonomy of austral monodontinetop shells (Mollusca: Gastropoda: 
Trochidae) inferred from DNA sequences [J]. Mol. Phylogenet. Evol., 37: 474-483.

Etter, R.J.; Boyle, E.E.; Glazier, A.; Jennings, R.M.; Dutra, E. and Chase, M.R. (2011). Phylogeography of a pan-Atlantic byssal protobranch bivalve Implications for evolution in the Deep Atlantic. Mol. Ecol., 20: 829-843.

Espiñeira, M.; González-Lavín, N.; Vieites, J.M. and Santaclara, F.J. (2009). Development of a method for the genetic identification of commercial bivalve species based on mitochondrial 18S rRNA sequences. J. Agric. Food Chem., 57: 495-502.

Feral, J.P. (2002). How useful are the genetic markers in attempts to understand and manage marine biodiversity? J. Exp. Mar. Biol. Ecol., 268, 121-145.

Folmer, O.; Black, M.; Hoeh, W.; Lutz, R. and Vrijenhoek, R. (1994). DNA primers for amplification of mitochondrial cytochrome $\mathrm{c}$ oxidase subunit 1 from diverse metazoan invertebrates. Mol. Mar. Biol. Biotechnol., 3: 294- 229.

Goloboff, P.A.; Catalano, S.A.; Marcos, M.J.; Szumik, C.A.; Salvador, A. J.; Källersjö, M. and Farris, J. S. (2009). "Phylogenetic analysis of 73060 taxa corroborates major eukaryotic groups". Cladistics, 25 (3): 211.

Hasegawa, M.; Kishino, H. and Yano, K. (1985). Dating of the human-ape splitting by a molecular clock of mitochondrial DNA. J. Mol. Evol., 22: 160-174.

Hebert, P.D.N.; Cywinska, A.; Ball, S. L. and de Waard, J. R. (2003): Biological identifications through DNA barcodes. Proc. R. Soc. Lond. (B) Biol. Sci., 270:313-321.

Huff, S.W.; Campbell, D.; Gustafson, D.L.; Lydeard, C.; Altaba, C.R. and Giribet, G. (2004). Investigations into the phylogenetic relationships of freshwater pearl mussels (Bivalvia, Margaritiferidae) based on molecular data, Implications for their taxonomy and biogeography. J. Moll.Stud., 70: 379- 388.

Luttikhuizen, P.C.; Drent, J.; Delden, W. and Piersma, T. (2003). Spatially structured genetic variation in abroadcast-spawning bivalve: quantitative versus molecular traits. J.Evol. Biol., 16: 260-272.

Machordom, A.; Araujo, R., Erpenbeck, D. and Ramos, M.A. (2003). Phylogeography and conservation genetics of endangered European Margaritiferidae (Bivalvia: Unionoidea), Biol. J. Linn. Soc., 78: 235-252.

Mahidol, C.; Na-Nakorn, U.; Sukmanomon, S.; Yoosuk, W.; Taniguchi, N. and Nguyen, T.T. (2007). Phylogenetic relationships among nine scallop species (Bivalvia, Pectinidae) inferred from nucleotide sequences of one mitochondrial and three nuclear regions. J. Shellfish Res., 26: 25-32.

Matsumoto, M. (2003). Phylogenetic analysis of the subclass Pteriomorphia (Bivalvia) from mtDNA COI sequences. Mol. Phylogenet. Evol., 27: 429-440.

Park, J.K. and Ơ Foighil, D. (2000). Genetic diversity of oceanic island Lasaea (Mollusxa: Bivalvia) lineages exceeds that of continental populations in the northwestern Atlantic. Biol. Bull., 198: 396-403.

Plazzi, F.; Ceregato, A.; Taviani, M. and Passamonti, M. (2011). A molecular phylogeny of bivalve mollusks: ancient radiations and divergences as revealed by mitochondrial genes. PloS ONE 6(11): e27147.

Roe, K.J.; Hartfield, P.D. and Lydeard, C. (2001). Phylogeographic analysis of the threatened and endangered superconglutinate- producing mussels of the genus Lampsilis (Bivalvia, Unionidae). Mol. Ecol., 10: 2225-2234.

Saitou, N. and Nei, M. (1987). The neighbor-joining method: a new method for reconstructing phylogenetic trees. Mol. Biol. and Evol., 4: 406-425. 
Smith, P.J.; McVeagh, S.M.; Won, Y.; Vrijenhoek, R.C. (2004). Genetic heterogeneity among New Zealand species of hydrothermal vent mussels (Mytilidae: Bathymodiolus). Mar. Biol., 144: 537-545.

Tamura, K.; Stecher, G.; Peterson, D.; Filipski, A. and Kumar, S. (2013). MEGA6: Molecular Evolutionary Genetics Analysis version 6.0. Mol. Biol. Evol., 30: 2725-2729.

Vierna, J.; Martinez-Lage, A. and. González-Tizón, A.M. (2010). Analysis of ITS1 and ITS2 sequences in Ensis razor shells, suitability as molecular markers at the population and species levels, and evolution of these ribosomal DNA spacers. Genome, 53: 23-34.

Westfall, K.M and Gardner, J.P.A. (2010). Genetic diversity of southern hemisphere blue mussels (Bivalvia, Mytilidae) and the identification of non-indigenous taxa. Biol. J. Linn. Soc., 101: 898-909.

Zardus, J.D.; Etter, R.J.; Chase, R.M.; Rex, M.A and Boyle, E.E. (2006). Bathymetric and geographic population structure in the pan-Atlantic deep-sea bivalve Deminucula atacellana (Schenck, 1939). Mol. Ecol., 15: 639-651.

\section{ARABIC SUMMARY}

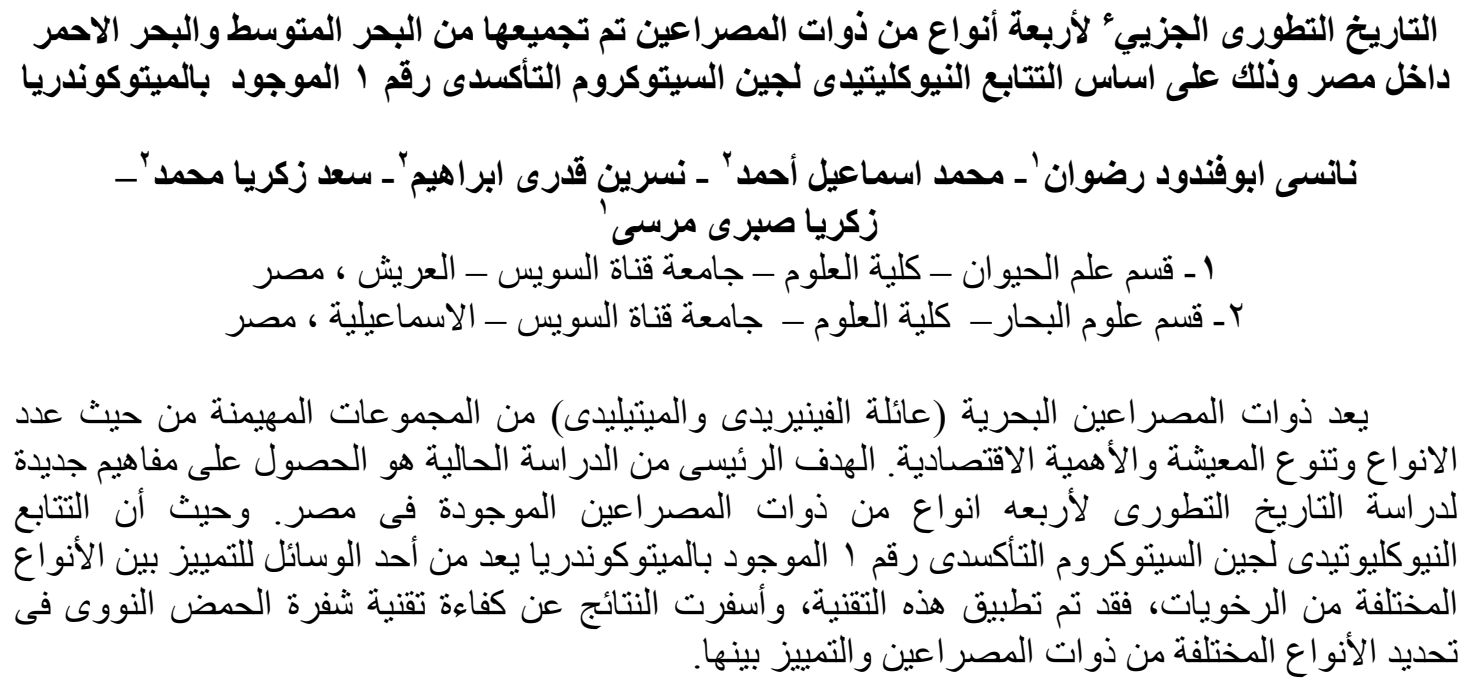

